\title{
The Thinking Fetus: Descartes at the Brink of Psychoanalysis
}

\author{
Cecilia Sjöholm | ORCID: 0000-0002-5333-4317 \\ Södertörn University, Stockholm, Sweden \\ cecilia.sjoholm@sh.se
}

\begin{abstract}
Descartes's philosophy of the passions is central for an understanding of seventeenthcentury ideas of affects and emotions and for the history of emotions overall. But does it have bearing today? In this article, I argue that Descartes raises the question of how the infantile relation to the maternal body influences the emotional life of the adult, a question that is still relevant for psychoanalysis and neuropsychology. In the philosophical scholarship on Descartes, the passages which pertain to the infant, or the fetus, and its alleged 'confused thought', are often quoted to demonstrate the challenges to dualism that are inherent in his own writings. However, I argue that these discussions point also to the complexity of the development of affects and emotions. In my reading, I show that Descartes's ideas of the passions can be seen as precursory to psychoanalytic theories of object relations. This opens the way for a new trajectory of research involving fantasy, instincts and repression in the Cartesian analysis of emotions and affects.
\end{abstract}

\section{Keywords}

Descartes - infantile life - object relations theory - affects - repression

\section{Rethinking Psychoanalysis in Descartes's Writings}

René Descartes's extraordinary autobiographic writings on his own dreams and his analyses of the state between wakefulness and sleep, associations 
and more have inspired and enticed psychoanalysis ever since Freud. ${ }^{1}$ The psychoanalytic readings of his philosophy have primarily focused on a split cogito - the question of how 'it' thinks in subjectivity. ${ }^{2}$ But we may also find precedents to theories on instincts, fantasy and repression, implying the presence of an object attached to the primary needs of the infant. This is virtually uncharted territory in studies of Descartes. The infant has a psychic life that will constitute the beginning of, and to a certain extent condition, the emotions, thoughts, memories and fantasies of the adult. Affects and emotions are with us already from birth, even from a fetal state of maternal symbiosis. How do these ideas - developed in letters, anatomical writings and images, and The Passions of the Soul (1649) - connect to psychoanalytic theories of object relations? At stake in this question is the hypothesis that Descartes's philosophy of passions shows that affects can be traced back to infantile attachments in early life, so-called objects. In the following, I will use the terms 'affects' and 'emotions' to designate the passions, diverging from Descartes's own separation between 'passions of the soul' and other passions. I instead designate Descartes's description of somatic experiences, such as pleasure and displeasure, as affects, and other, intrapsychic experiences, such as love and hate, as emotions. These designations do not follow a theory at will; they are descriptions rather than definitions.

The fact that Descartes gives attention to infantile life has been interpreted as an expression of personal trauma - Descartes lost his mother as an infant. Given the strong biographical feature of his writings in general, such interpretations may seem compelling. ${ }^{3}$ Most would abstain from philosophical

1 Sigmund Freud, 'Some Dreams of Descartes: A Letter to Maxime Leroy,' in SE XXI, 203-04. (SE refers to Freud, The Standard Edition of the Complete Psychological Works, ed. and trans. James Strachey and Anna Freud, 24 vols (London: Hogarth Press, 1953-74)). In Freud's reading, Descartes's dreams appear to be 'from above,' of intellectual rather than associative content.

2 See Mladen Dolar, 'Cogito as the Subject of the Unconscious', in Cogito and the Unconscious, ed. Slavoj Zizek (Cambridge, MA: MIT Press, 1998), 11-41; Joël Sipos, Lacan et Descartes: la tentation métaphysique (Paris: PUF, 1994), 275-306; Humphrey Morris, 'Reflections of Lacan: His Origins in Descartes and Freud,' Psychoanalytic Quarterly 57, no. 2 (1988): 186-208; Adrianna M. Paliyenko, 'Postmodern Turns against the Cartesian Subject: Descartes's "I," Lacan's Other,' in Feminist Interpretations of René Descartes, ed. Susan Bordo (Pittsburgh: Pennsylvania State University Press, 1999), 141-66.

3 Feuer performs an analysis of Cartesian 'anxiety' with reference to these personal experiences, adding also that the often commented section in Passions about a husband secretly feeling relief at his wife's passing is referring to his father. Lewis S. Feuer, 'Anxiety and Philosophy: 
psychobiography today. But it is unquestionable that in an early modern universe of humours and fluids, Descartes's natural philosophy and anthropology stand out for the way they rethink the attachments of the infant. This is not only relevant for the ongoing reassessment of Cartesian dualism. The more pressing question is if Descartes's speculations on the life of the infant may open new avenues for interpreting Descartes as a precursor to psychoanalysis.

What is the relation between mother and child in Descartes's work? How is it described, and what role does it play? In letters, commentary and anatomical descriptions, Descartes holds it up to scrutiny - both before and after birth. Affects and emotions emerge in the relation between the maternal body and the child. This belongs to an area of questioning which Descartes himself called anatomical. It is rarely seen to be related to the intriguing debate on the 'thinking fetus', which Descartes was engaged in with correspondents and commentators - dedicated to the question of the origin of the mind. In the second chapter of the Meditations (1641), he affirms that the assumption I am, I exist must necessarily be true. No God-deceiver can make him think that he is 'nothing' as long as he conceives of himself as something, a 'thing that thinks ... that doubts, understands, affirms, denies, is willing, is unwilling, and also imagines and has sensory perceptions. ${ }^{4}$ In the Discourse on Method (1637), the metaphysical fundament of dualism is established. ${ }^{5}$ Many have commented on Passions of the Soul as an attempt to overcome that dualism. ${ }^{6}$ This is indeed one of the ambitions mentioned by Descartes himself.7 In a letter to Elisabeth of Bohemia Descartes describes three different faculties of knowledge: the pure, metaphysical understanding that uses concepts, the use of intellect and imagination, and the bodily awareness in everyday life where body and mind are joined. ${ }^{8}$ From an everyday perspective, metaphysical

The Case of Descartes,' American Imago 20, no. 4 (1963): $411-49$ (417). See also Rodis-Lewis on the guilt associated with the maternal death: Geneviève Rodis-Lewis, Descartes (Paris: Calmann-Lévy, 1995), 17-22.

4 AT VII, 17-29; PW II, 17-19. (AT refers to Descartes, CEuvres, ed. Charles Adam and Paul Tannery, rev. edn, 11 vols (Paris: Vrin, 1964-74); PW to The Philosophical Writings of Descartes, trans. Johan Cottingham, Robert Stoothoff, and Dugald Murdoch, 3 vols (Cambridge: Cambridge University Press, 1984)).

5 AT VI, 32; PW I, 127.

6 Lilli Alanen has argued that passions in Descartes are modes of the mind, or thoughts, caused by modes of the body, and that Descartes implies that we may never assert the relation between body and mind through philosophical means. This, in turn, is a philosophical statement; individual histories will determine the way in which affects are produced and received in each unique person. Lilli Alanen, Descartes's Concept of Mind (Cambridge, MA: Harvard University Press, 2003), 172-78.

7 AT IV, 4O7-13, Descartes to Elisabeth of Bohemia, May 1646.

8 AT III, 691-94, Descartes to Elisabeth, 28 June 1643; PW III, 227-28. 
dualism, the separation between the mind or res cogitans, and the body, res extensa, does not seem to make sense.

A concept destined to challenge and/or raise debate on the distinction between mind and body, the idea of the thinking infant, was launched in a metaphysical discussion of principles. But the metaphysical issues slide into a discourse on the infant which was present in earlier anatomical work. In this way, Descartes, just like the object relations theory of Sigmund Freud and Melanie Klein in particular, uses the child to demonstrate that the distinction between mind and body cannot be upheld. Emotions and affects hark back to the infant's needs, its polymorphous sexual sensitivity and its relation to the maternal body, actualising the psychoanalytic notions of instinct, fantasy and repression. Descartes conceives of emotional memory as traces incorporated since childhood. It cannot be produced at will; it comes to us without us knowing why.

The debate on the 'thinking fetus' engaged thinkers such as Antoine Arnauld and Elisabeth of Bohemia in the early 1640s. The primary question was: when does thought begin? Can we conceive of a human subject without a mind, such as a fetus or a small child? In parallel to these discussions, Descartes speculated on the development of the human body: these ideas hark back to early writings, such as the Treatise on Man, which he began in the late 1620 . They were also developed in the Description of the Human Body, where Descartes discusses the biological constitution of the human body (1647/48, published posthumously by Clerselier in 1664). The writings on anatomy ran in parallel with the metaphysical work on the subject of thought. But they are not unrelated; they offer a background to the question of what thought is and how it defines the human subject. But the works on anatomy also offer speculations on how affect and thought intertwine. Here Descartes returns not just to childhood, but to the very origins of the fetus in the maternal womb. When Description of the Human Body was published, Clerselier used the title The Formation of the Fetus, although it was meant to encompass only the final part of the treatise on anatomy, which is how I will use it. ${ }^{9}$

9 Clerselier produced the 1664 illustrated edition of $L^{\prime} H o m m e$, which is included in the bigger work Le Monde. As Annie Bitbol-Hespériès has shown, no script was found which carries the title La formation du foetus. In Descartes' Treatise on Man and its Reception, ed. Delphine Antoine-Mahut, Stephen Gaukroger (Cham: Springer International Publishing 2016), 33. 
Embryology was usually the study of animal fetal development. Descartes looked at bloodstreams, the development of the lungs, the connection between fetus and maternal body. This would imply following the development of that connection until its rupture, a development that was never fully completed in a coherent way in the earlier work of the Treatise on Man..$^{10}$ Descartes was not only trying to link animal embryology with human anatomy. Anatomy was to a certain extent intertwined with metaphysical questioning." ${ }^{11}$ Through the method of dissection, Descartes observed processes that are usually not disclosed, aiming to understand how internal organs help produce not only perceptions, but also affects. The actual, physical dissections, demonstrating the beginning of life in the maternal womb, were likely performed on a sheep. But they were used to shed light on what is most distinctly human - the capacity to think and feel. In this way, Formation of the Fetus has a distinct bearing on metaphysical discussions on the cogito in Meditations on First Philosophy.

Descartes points out that the inner organs are not influenced by what we want or what we think. We cannot control reflexes sparked by hunger or pain through sheer willpower. ${ }^{12}$ This is, to some extent, a reason for maintaining dualism. The introduction to Description of the Human Body argues that there is a distinct difference between thought and the mere mechanics, that is, the anatomical functioning of the body. When we are children, we are not aware of this: we think that we can master our bodies through our willpower. ${ }^{13}$ But there is a distinct split between the mind and the body of reflexes. In concluding this, Descartes establishes a certain form of dualism.

But with the formation of the fetus, the distinction between the body's 'inside' and the senses blurs. The Formation of the Fetus tells the story of how humans are formed from conception to birth, invisible traces joining mind and

$10 \quad$ As described by Delphine Antoine-Mahut, 'The Story of L'Homme,' in Descartes' Treatise on Man and its Reception, ed. Delphine Antoine-Mahut and Stephen Gaukroger (Cham: Springer, 2016), $1-33$.

11 For a convincing line of argument on this, see Bitbol-Hésperiès, 'Cartesian Physiology,' in Descartes' Natural Philosophy, ed. Stephen Gaukroger, John Schuster, and John Sutton (London: Routledge, 2000), 375.

12 Gary Hatfield has sketched the vast and historically varied reception of Descartes's neurological and psychological hypotheses, including Ivan Pavlov's praise of the discovery of reflexes. Hatfield shows that recent discussion of Descartes in the neurosciences looks at his physiological and anatomical writings less as 'mechanistic' and more as a complex theory connecting neurological dispositions, memory, behaviours and emotional responses. Hatfield, 'L'Homme in Psychology and Neuroscience,' in Descartes' Treatise on Man and its Reception, ed. Antoine-Mahut and Gaukroger, 269-85. 
body. ${ }^{14}$ These traces, which distinctly cross the mind-body divide, may pass from mother to child. The body of a fetus, as well as that of a young child, is thought to be more permeable than that of an adult body. In utero, infant and maternal body are in symbiosis through 'the external surface of the skin called the "after-birth", which envelops the child before it is born.'15 This symbiosis is of the utmost importance for how the individual develops physically. It may even cause the physical imprint of external marks on the body of the child: a mother's perceptions can become imprinted on the limbs of the fetus as they form in the womb, just like a tattoo. ${ }^{16}$ This idea also occurs in Optics: what the mother perceives when pregnant can make a mark on the body of the child. Even her fantasies may have the same effect. ${ }^{17}$ This description of the symbiotic relation between mother and child was in flux in Descartes's time. ${ }^{18}$ However, Descartes moves beyond sheer physical speculation on the origin of birthmarks, for instance. He extends his speculations towards the life of the mind. In letters and in Passions of the Soul, the psychic life of the infant is not determined by an exclusionary logic, that is, by either body or mind, but by a symbiosis which cuts across such a divide. This presents a challenge to a conception of body - mind dualism, which may seem to oppose what Descartes has claimed himself in other writings. But it has other implications as well. Descartes also challenged the notion that the infantile subject should be seen as a 'little cogito', that is, as an entity of pure reflection. Instead, he speculated on the impact of the maternal body and its symbiotic relation to the child, on the development of the body and mind of the child.

Descartes brings this up himself directly in a philosophico-theological debate which was published in conjunction with the first edition of the Meditations (1641). Having sent the manuscript of the Meditations to friends and scholars, Descartes took great care to respond distinctly to their replies, the result being an appendix to the Meditations. The question of the 'thinking fetus' is raised in the exchange between the theologian Antoine Arnauld

14 AT III, 424; PW III, 190.

15 AT XI, 284; Descartes, The World and Other Writings, trans. Stephen Gaukroger (Cambridge: Cambridge University Press, 2004), 204.

16 AT X, 178; AT XI, 177, Descartes, The World, 150; PW I, 106.

17 See Discourse 5 in Optics, AT VI, 128; Descartes, Discourse on Method, Optics, Geometry and Meteorology, trans. Paul J. Olscamp (Indianapolis: Hackett, 2001), 10o. See also AT I, 153, Descartes to Mersenne, 27 May 1630; PW III, 26.

18 AT VI, 129. See Bitbol-Hespériès, 'Cartesian Physiology'’ 37o. Marie-Hélène Huet has shown it to be a common Renaissance idea and pointed to it being a developed idea in Malebranche, for instance, who used Descartes to argue that the mother's perceptions, affects and imagination caused direct imprints on the brain of the child. Huet, Monstrous Imagination (Cambridge, MA: Harvard University Press, 1993), 47-50. 
and Descartes (whose responses were mediated by Mersenne). To Arnauld, Descartes's metaphysical description of the cogito has absurd consequences. The cogito conceives of its existence through its reflection over itself; it is a thing that thinks. ${ }^{19}$ This implies that it is something only as long as it conceives of itself, Arnauld contends; Descartes lays it down as certain that there can be nothing in him, in so far as he is a thinking thing, of which he is not aware..20 But the infant in the mother's womb has a mind, Arnauld argues, even if the infant does not know or reflect over it.

Descartes, in turn, vehemently objects to Arnauld's objections. There can be nothing in the mind that is not a thought or dependent on a thought: 'the mind begins to think as soon as it is implanted in the body of an infant, ... it is immediately aware of its thoughts, even though it does not remember this afterwards because the impressions of these thoughts do not remain in the memory.' ${ }^{21}$ In other words, the fetus is thinking. This means simply that Descartes insists that the child has a mind. But it forgets what it has been thinking. Adults do not remember their infantile life. Why? Could it be that the thoughts of the child should be conceived in a different way from the thoughts of an adult?

Exchanges with Pierre Gassendi suggest how this could be done. Gassendi asks if Descartes could remember what he was thinking about in the womb, or at birth. The reflective powers of the mind of an infant in the womb must be meagre, virtually non-existent. ${ }^{22}$ We are not always thinking - not when we are asleep, and not when we are small children. To this, Descartes responds that the amnesia of childhood is due to memory not being developed. A child's brain does not carry the 'traces' that connect impressions with other memories. ${ }^{23}$ Here the question of the child's mind becomes developmental. ${ }^{24}$ In an exchange with an unknown author named Hyperaspites, the argument with Gassendi - to which Hyperaspites seems to refer - continues. Here, a new dimension of the problem emerges - it appears that the moment in which

19 AT VII, 25, 28; PW II, 17, 19.

20 AT XI, 167; PW II, 15 O.

21 AT IX, 19O; AT VII, 246; PW II, 171-72.

22 AT VII, 264; PW II, 184.

23 AT VII, 357; PW II, 247.

24 Rebecca Wilkin has given an account of the exchange from this point of view, arguing that Descartes's arguments concerning the fetus underline his overall argument that in our everyday lives, we usually perceive of ourselves as beings of both body and mind. The shock of Descartes's considerations of the fetus, Wilkin argues, historically related to his joining the idea of a biological entity and a thinking being; they had hitherto stemmed from two different ontologies and not been joined. Wilkin, 'Descartes, Individualism, and the Fetal Subject,' differences: A Journal of Feminist Cultural Studies 19, no. 1 (2008): 96-127 (106). 
the mind is infused in the body is undecidable. Therefore, the moment in which 'thought' begins, before or after birth, is also undecidable. This has some bearing on the fact that we cannot recall it afterwards. Even inside a mother's womb, a mind 'is always thinking'. ${ }^{25}$ But sometimes the mind appears to be 'newly united' to the body at birth. ${ }^{26}$ This undecidability of the actual birth of the 'thinking' infant follows Descartes in his writings throughout - when he talks about the infant, it is not always certain if he is talking about the unborn child or the young child. This fluid nature of the 'infant' stresses its belonging to a maternal sphere.

The character of 'thoughts' also has a fluid nature. If the fetus is thinking, what is it thinking of? Of course, a fetus cannot, Descartes says with dry humour 'meditate on metaphysics in its mother's womb, not at all. ${ }^{27}$ This is because it is so invested in its own body that it cannot be detached from it. The infant may not reflect on the extension of being or the difference between being and extension. But it thinks precisely because it is a mind connected to a body, even in the womb. Thus, our first thoughts are directed towards primary needs and physical afflictions:

a mind newly united to an infant's body is wholly occupied in conceiving in a confused way or feeling the ideas of pain, pleasure, heat, cold and other such ideas which arise from its union and, as it were, intermingling with the body. ${ }^{28}$

In this passage, we encounter the notion of 'confused thoughts' - when the mind is impinged on by the body. As stated at the beginning of the Treatise on Man, children cannot distinguish between will and corporeal reflexes. The mind of the child 'conceives of' its needs. It is not clear what the difference is between the thinking of one's needs and the very experience of needs. This has to do with the very status of infantile life, as being enwrapped in needs. As explained in a text that may have been authored a few years earlier, the conversations with Burman: 'the mind is so swamped inside the body that the only thoughts it has are those which result from the way in which the body is affected'. Responding to its needs, the body 'has an obstructive effect on the

25 AT III, 423, Descartes to Hyperaspistes, August 1641; PW III, 189.

26 AT III, 424; PW III, 190.

27 AT III, 424; PW III, 189.

28 AT III, 424; PW III, 19o. The passage is taken from the letter to Hyperaspistes, which can be read as a response to Gassendi. 
soul' and is 'a hindrance to the mind in its thinking. ${ }^{29}$ In early childhood, the mind is so closely tied to the body that the only thoughts that reach it are those of corporeal sensory awareness. ${ }^{30}$ The thoughts of the child are associated with pleasure and pain or things that are either harmful or enjoyable to the body in a direct manner. In infancy, affects and needs, which are produced by the body, impinge on the mind. ${ }^{31}$ Not only the child has 'confused thoughts' the body impinges also on the mind of adults. ${ }^{32}$ But the child serves as a model for a subject with 'confused thoughts' - the thoughts of the infant are close to that of someone who is half asleep, or sick - the mind is enwrapped by an acute corporeal and sensory awareness and often fixated on a single sensation. The child, as well as the sleeping and sick individual, is simply too much body.

In this way, 'confused thoughts' are typical for, but by no means restricted to, the infant. The very idea of confused thoughts, neither wholly mind nor wholly body, is also a metaphysical problem, or perhaps a problem of cognition. ${ }^{33}$ Philosophers, also, fail to distinguish between mind and body. Our 'earliest childhood judgements' reflect the conflation between body and soul in philosophy at large - philosophers are victims of the prejudices that the Meditations tries to undo, demonstrating the distinction between sensory experience and knowledge. ${ }^{34}$ But 'confused thought' applies also to a certain notion of development, when the mind 'does not work so well'. That is not because the body impedes the mind. It is because the mind, to a certain extent, depends on the body. ${ }^{35}$ And the body of a child is not fully developed.

29 Descartes, Descartes' Conversation with Burman, trans. John Cottingham (Oxford: Clarendon Press, 1976), 8.

30 See Article 71 in Principles of Philosophy, Part I, AT VIIIA, 35; PW I, 218. See also AT III, 424; PW III, 189.

31 Descartes, Conversation with Burman, 8. See also AT III, 424; PW III, 190.

32 Descartes, Conversation with Burman, 8.

33 Lilli Alanen has an interpretation of 'confused thoughts' which pertains to emotional cognition in Descartes, rather than psychic life. She describes the passions originating in the body as modes of thought and the kind of knowledge that the passions may produce as inherently confused, since it belongs to the hybrid domain situated between body and mind. Alanen, Descartes's Concept of Mind, 64-65.

34 AT III, 420, Descartes to de Launay, 22 July 1641; PW III, 188. As Daniel Garber has argued, childhood, in Descartes's writings, is a period in which prejudices are established with regard to our knowledge of the outside world: our sensory experience, rather than reason, becomes a primary source for knowledge of the outside world. Garber, Descartes Embodied. Reading Cartesian Philosophy through Cartesian Science (Cambridge: Cambridge University Press, 2001), 230-33.

35 André Gombray has noted that Freud and Descartes differ in the sense that Descartes does not find the mind of the child to be deficient in any way. Gombray, 'Sigmund Descartes?', 
Descartes's concept of 'thought' is not the same as res cogitans - 'thought' is not always free and distinct from the body. It applies to a wider range of mental phenomena that includes perceptions, sensations, affects and emotions. In Passions of the Soul, affects and emotions are 'thought'. One may take the notion of 'confused thought' to point to the need for a new metaphysics - and the cogito as a solution to that, defining thought as reflected abstraction. ${ }^{36}$ But Descartes's notion that the infant - and the fetus - are thinking, although confusedly, also points to the fact that 'thought' in Descartes is a generous concept that pertains also to developmental stages. In the following, we will see how this open notion of thought is used in descriptions of the symbiotic relation with the maternal body, and of the unconscious.

The maternal body presents itself not only in Descartes's embryology but also in his work on emotions and affects - where love and hate are dominant. Their status as primary or basic emotions is developed in Descartes's final complete book, The Passions of the Soul. These are primary emotions because other emotions can be deduced from them. They are dependent on original somatic affects; they direct us towards the maternal body or make us reject it. The relation to the maternal body is dominated by what Melanie Klein calls 'instincts'. The physiological and affective descriptions of love and hate derive from infantile life.

Passions of the Soul explains the way in which emotions interact with perceptions and other forms of knowledge. It has often been read as a Stoic treatise, occupied with the deliberate 'therapy' of emotions and affects. ${ }^{37}$ But few have commented on the fact that it is also an archaeology of emotions, which goes all the way back to the life of the infant. One exception is John

Philosophy 83, no. 325 (2008): 293-310. But neither does Freud; both describe forms of cognitive and affective developments.

36 Jean-Luc Marion, On Descartes' Passive Thought: The Myth of Cartesian Dualism, trans. Christina M. Gschwandtner (Chicago: University of Chicago Press, 2018), 139-40.

37 Erec Koch has described how this 'therapy' developed in correspondence with Elisabeth of Bohemia, who suffered from depression, where Descartes gave instructions for a self-help therapy that would connect emotions and representations. Erec R. Koch, The Aesthetic Body. Passion, Sensibility and Corporeality in Seventeenth Century France (Newark, DE: University of Delaware Press, 2010), 65-68. See also John Sutton, 'Controlling the Passions: Passion, Memory and the Moral Physiology of the Self in Seventeenth-Century Physiology', in The Soft Underbelly of Reason, ed. Stephen Gaukroger (London: Routledge, 1998), 115-47. 
Cottingham, who has seen the poignancy of Descartes's description of the role that emotions and affects play in early life. Cottingham compares Descartes's descriptions of the infant with those of Freud. He still reads Descartes's treatise as a 'therapy' of emotions and affects. ${ }^{38}$ Descartes's precursory relation to psychoanalysis can, however, be developed in another direction - towards the question of object relations.

Freud, in his first model of the ego, Project for a Scientific Psychology (Entwurf einer Psychologie, 1895), describes how the ego develops in relation to strong corporeal experiences of pleasure and displeasure. Unsatisfied corporeal needs, such as hunger, cause tension and displeasure. Enjoyment, in turn, is explained as a discharge of tension. The original mode of this is breastfeeding: an infant seeks the breast for satisfaction. Through a complex dialectic between need and denial, it may also seek satisfaction in a fantasy. It may even be invaded by hallucinatory fantasies, succumbing to the pleasure principle to the extent that it may threaten the development of the ego. ${ }^{39}$ What is at stake is how Freud shows the fragility of the ego in relation to the maternal breast as primary object. As in Descartes, there is no distinct moment in which the ego has a clear sense of itself as distinguished from the breast; it is a developmental process, and traces of the process will remain in the unconscious also in adult life.

Descartes's developmental notion of the infant, also, allows us to discern a fragile ego, dependent on experiences of pleasure and satisfaction afforded by a primary object, experiences that leave their mark as traces of mind and body. In Descartes's Principles of Philosophy (1644), the infant cannot engage in anything but those thoughts by means of which it had a sensory awareness of what was happening to the body' ${ }^{40}$ Later, the child begins to discern a difference between itself and the outside world by distinguishing between pleasure and displeasure. ${ }^{41}$ Descartes deploys the word 'affectus' to describe the motions and affects that result from this process. ${ }^{42}$ Passions 'affect' us. They come to us, regardless of our will. We cannot 'make' emotions or affects. As we shall see, Descartes, like Freud, finds their root in early experiences of pleasure and satisfaction, relying on the gastric and nutritional systems.

38 John Cottingham, Philosophy and the Good Life:Reason and the Passions in Greek, Cartesian and Psychoanalytic Ethics (Cambridge: Cambridge University Press, 1998), 80-96.

39 Freud, 'Project for a Scientific Psychology', in SE I, 358-59.

40 АТ ІХв, 35; PW I, 218.

41 AT IXB, 35; PW I, 219.

42 See the foreword by Geneviève Rodis Levis to The Passions of the Soul, trans. Stephen Voss (Indianapolis: Hackett, 1989), xx. 
In Passions of the Soul, Descartes distinguishes between 'passions of the soul', which we would translate as a concept closer to emotions, and passions that appear with sheer physical force. These are intensities between bodies, visceral forces in which we are immersed, and over which our conscience holds no control. Passions of the soul are what Descartes calls 'thoughts'. Although they are perhaps confused thoughts, they are not sheer unconscious forces. We might call them emotions, moods, humours or moral forms of sensibility. They are 'internal sensations' that can also be experienced as physical phenomena, but not as sheer force. ${ }^{43}$ Passions that appear as sheer physical sensation are not 'passions of the soul. What connects both kinds of passions is the way in which they simply seem to hit us, beyond our willpower. Descartes will be treating the passions 'as a physician', he writes in the introduction to Passions of the Soul. This means that he is writing as a natural philosopher - he is returning, in many respects, to his anatomical writing. It also means that Descartes is aiming to demonstrate the dimension of affects that surpasses 'thoughts'. Certain affects are wholly somatic; they are literally 'in' our bodies. ${ }^{44}$ What distinguishes the corporeal production of affects and the emotional 'thought' is not primarily the mind-body distinction..$^{45}$ It is the fact that corporeal affects, although they would appear to be subject to scientific explanation, are a bundle of unpredictable experiences. Affects are perceptions in the most general sense - they are imposed on us. ${ }^{46}$ What is of concern to Descartes here is not just the relation between body and mind or the way in which we may 'treat' emotions and affects. It is the way in which the source of emotions and affects is unavailable to reason. ${ }^{47}$ Searching for that source, Descartes's inquiries move into the same territories as Freud's.

Small children have a super-sensitivity that stands in contrast to the free rationality of the adult; their minds are 'swamped by affects'. 48 This is not, as we have seen, because their minds are less developed. The affective inundation

AT XI, 342; Descartes, The Passions of the Soul, 28.

44 See correspondence with Elisabeth of Bohemia, in Descartes, Passions of the Soul, 17. Descartes's notions of physiology in this work and others, such as De l'homme, were on the one hand inspired by physiological models, such as Harvey's, but also came to hold a canonical position in the teaching of medicine in the Netherlands and was widespread within the scientific community in Europe. See Koch, The Aesthetic Body, 28-33. AT VII, 81-83; PW II, 56-57.

46 AT XI, 346-48; Descartes, Passions of the Soul, 32.

47 Alanen has described Descartes's concept of passion as implying an immediate somatic effect on the body; what we see makes us act and behave in a certain way. As perceptions, passions are not object to judgement. See Alanen, 'The Psycho-physiology of Passions,' in Descartes's Concept of Mind, 183-85.

Descartes, Conversation with Burman, 8. See also AT III, 424; PW III, 190. 
derives from the conditions of infantile life. Certain affects, Descartes explains, are with us 'before birth' ${ }^{49}$ Others, however, develop with primary needs - and this is where we may begin to search for a 'pre-psychoanalytical' genealogy of object attachment. The infantile body, to Descartes, is dominated by needs that only the maternal body can respond to. Love is the most original emotion; the child is wholly dominated by love for the mother. Where do physical affects end and 'inner' emotions begin? This is explained in terms of object relations.

Preceding the publication of Passions of the Soul, Descartes discussed the archaic roots of emotions in a famous exchange with Chanut, who was the French ambassador to Sweden. This exchange responds to a question indirectly posed to Descartes by Queen Christina: which emotion is 'worse if immoderate and abused, love or hatred?'50 The so-called 'letter of love' is often invoked by philosophers and theologians for the way in which it distinguishes intellectual love and 'confused thoughts': the impingement on the mind of corporeal and instinctual love. ${ }^{51}$ But not enough attention has been offered to the physical child and the 'thinking fetus', which are to be found at the origins of the explanations of the passions. In explaining love, Descartes declares four passions to be original to the soul: love, joy, sadness and desire. All of these may exist independently of a body; there may even be a certain rationality to them. ${ }^{52} \mathrm{But}$ since we are beings of both body and mind, they exist also at a corporeal level. Love can be 'confused thought', conjoined to corporeal sensation:

in love a mysterious heat is felt around the heart, and a great abundance of blood in the lungs, which makes us open our arms as if to embrace something, and this inclines the soul to join to itself willingly the object presented to it. ${ }^{53}$

It is in the nature of love to arise as 'confused thought', since love is 'aroused by some motion of the nerves'. ${ }^{44}$ These motions are aroused at birth, where an intrinsic link between love and physical state is created: 'there is no doubt

49 AT IV, 6o5, Descartes to Chanut, 1 February 1647; PW III, 308.

50 AT IV, 6o1; PW III, 306. See discussion in Rodis-Lewis, Descartes, 262-63.

51 AT IV, 6o2; PW III, 306. See also Denis Kambouchner, 'La Subjectivité cartésienne et l'amour,' in Les Passions à l'âge classique, ed. Pierre-François Moreau (Paris: PUF, 2006), 77-97; Alberto Frigo, 'A Very Obscure Definition: Descartes's Account of Love in the Passions of the Soul and its Scholastic Background,' British Journal for the History of Philosophy 24 (2016): 1097-1116.

$5^{2}$ AT IV, 6o1; PW III, 306.

53 AT IV, 6o2; PW III, 307.

54 AT IV, 6о2; PW III, 307. 
that the bodily conditions that were the first to accompany our thoughts when we came into the world must have become more closely connected with them than those which accompany them later'.55 Descartes traces the origin of emotions and affects to distinct scenes of infantile life, to birth, and to breastfeeding where we experience immediate enjoyment. This enjoyment derives from immediate nourishment: 'it is scarcely likely that the body would have been in a good condition unless there were nearby some matter suitable for food'. ${ }^{56}$ Love is then the first emotion that the soul feels, and - if there is no 'food' sadness, or hatred.

These passages are offered by Descartes as a genealogy to an understanding of love as a passion of the soul. We are capable of feeling 'intellectual' love since we are given to love in its 'confused' form already from birth. Linked to love is the original affect of enjoyment, of the nourishment received from the maternal body, which will then develop into love. ${ }^{57}$ These connections - between 'rational love' and the 'confused sensations of our childhood' - later allow us to choose objects - what is worthy of love. ${ }^{58}$ In the letter, the 'food' which offers enjoyment to the child of confused thought could of course be read as metaphysical or allegorical 'food'. But what is at stake is rather the description of an all-encompassing affective state of infantile life, when rational love has not yet gotten rid of the 'confusion'. In a letter to Elisabeth, which was written the year before, Descartes describes infantile life in similar terms, but without the purpose of defining rational love. Instead, he is returning to notions of how the passions originate, which to Descartes is connected to the formation of the body, the description of which 'is so difficult that I would not yet dare to undertake it'.59 Love goes back to the moment when infants are newborn. This is often quoted as establishing a connection between body and mind, thus overcoming dualism. ${ }^{60}$ But in the letter, Descartes explains why certain affects will remain in the body, so to speak, from birth to adult life. For some people, the first thing that upset them as babies was not getting enough food, while for others, it was getting food that was bad for them. This experience of deprivation will forever be connected to 'the passion of sadness'.61 This is an extraordinary observation, explaining the way in which love, or deprivation of

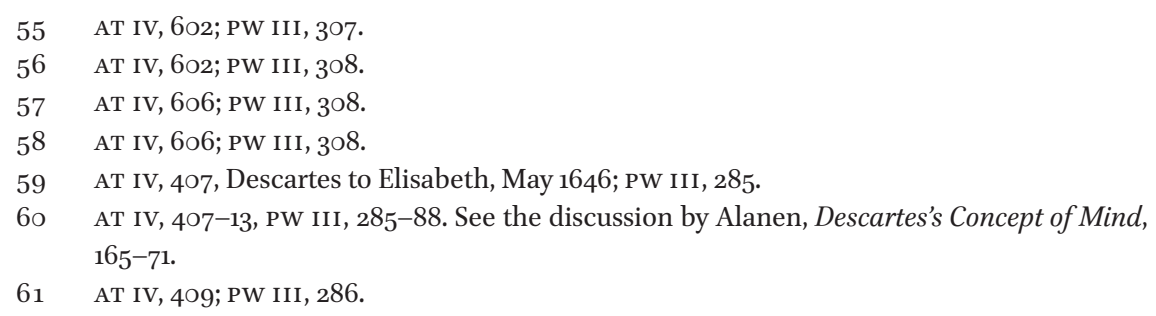


love, is intimately connected to breastfeeding - the breast becomes a primary object of affects. What Descartes describes is not only an infant attached to the maternal body through its needs. What he describes is the development of psychic life in and through the object. In fact, there is no basic passion defined by Descartes that is not fundamentally directed towards an object or which does not have its origin in an archaic relation to the maternal body.

Remarkable is, also, that the breast can also be a fantasy. In Passions of the Soul, Descartes returns to the suggestion of an original moment which crosses all distinct borders between the metaphysical, the physiological and the anthropological. Love is 'our soul's first passions, when it was originally joined to our body', experienced through a flow of 'blood, or other juice entering the heart, sometimes being more suitable nourishment than the usual for maintaining the heat in it which is the principle of life. ${ }^{62}$ This moment, as we have seen in his reflections on the 'thinking fetus', is both physiological and metaphysical. The 'nourishment' is in the soul (love) but also in the body, producing an experience of pleasure which goes back to the time when we were newborns, 'as our life was just beginning', or precedes birth, through veins nourishing and maintaining 'the heat of the heart', which is enjoyment. ${ }^{63}$ The 'nourishment' is an original factor connecting pleasure to the representation of an 'object of love', which to Descartes may well appear in the mind, and not in reality, so to speak. Such a representation causes the 'alimentary juice' to flow much stronger than blood, with more heat. This, in turn, strengthens 'the impression which the first thought of the lovable object has formed there (in the brain)', and to 'compel the soul to dwell upon that thought. And this is what the passion of Love consists in.' ${ }^{64}$ Passages such as these distinctly interconnect the representation of a primary object of love with an originary kind of nourishment, or alimentary juice, in French a 'suc' or 'aliment' - the first connected with biological life, the latter maintaining the principle of life in the seventeenth-century dictionary of Furetière. Neither of these are direct translations of breastfeeding, but could well be interpreted as its transposition, a kind of fluid which Descartes wants to keep both spiritual and physiological. The many physiological references to

62 AT XI, 407; Descartes, Passions of the Soul, 76-77. As Annie Bitbol-Hespériès has shown, the question of the principle of life was a dominant question for Descartes, pointing to the question of generation, the relation between body and soul, of biology and physiology, as well as the construct of animal spirits. In this trajectory, the heat of the heart was a central notion, extending from his physiology into his philosophy of emotions, offering a point which defines all living beings, and not just human beings. Bitbol-Hespériès, Le Principe de vie chez Descartes (Paris: Vrin, 1990), 55-102.

63 At XI, 408; Descartes, Passions of the Soul, 77.

64 AT XI, 404; Descartes, Passions of the Soul, 74. 
the symbiosis between mother and child that is maintained throughout the chapters on love in Passions of the Soul attach nourishment to a mental imprint of a first object, which is immediately connected with affects.

But these recurring passages do not offer a pre-psychoanalytic theory of the object only through love and enjoyment. They also conceive of deprivation at the roots of human psychic life. In Passions of the Soul, an 'alien juice' may enter the body which causes strong physiological reactions: vomit, but also hatred. ${ }^{65}$ This mysterious juice, a nourishment from the outside which the body rejects, is easy to associate with the maternal breast-milk turned sour. It is not only an object of satisfaction. When the child is deprived of it, as Descartes says in a letter to Chanut, sadness follows - and then hate. ${ }^{66}$ These archaic emotions which are with us already before birth - are induced by corporeal instincts, and appear as confused thoughts. As long as the body depends on basic needs, no other emotions can develop. Emotions do not derive from the judgement of objects, but from the relation to the maternal breast.

Early psychoanalytic theories of object relations offer similar genealogies. In Freud's Three Essays on Sexuality, the most archaic experience of pleasure comes with the suckling of the maternal breast: 'no doubt stimulation by the warm flow of milk is the cause of the pleasurable sensation', ${ }^{67}$ To Melanie Klein, also, love is the most complex human emotion. It originates in the 'mental life of the baby' - for whom the mother is the first object of love. ${ }^{68}$ To Klein, like Descartes, psychic life is present already from the time of birth. Also, emotions are intrinsically linked to objects. As Julia Kristeva has put it: there is 'no instinctual urge, no anxiety situation, no mental process which does not involve objects, external or internal; in other words, object-relations are at the centre of emotional life' ${ }^{69}$ Melanie Klein describes a relation to the world defined in a pre-Oedipal phase, where the breasts are a fountain of milk, 'coveted as organs of receptivity and bounty from the time when the libidinal position is purely oral. ${ }^{70}$ For Klein, psychic life begins with pleasure, a pleasure deriving from the stimulation of the mouth sucking the breast of the mother. Nourishment is not only alleviation of hunger but enjoyment, what Descartes calls the 'heat of the heart': 'Pleasure is experienced also when the warm

\footnotetext{
65 At XI, 408; Descartes, Passions of the Soul, 77.

66 AT IV, 6o5, Descartes to Chanut, 1 February 1647; PW III, 308.

67 Freud, Three Essays of Sexuality, in SE VII, 181.

68 Melanie Klein, 'Love, Guilt and Reparation,' in Love, Guilt and Reparation and Other Works, (London: Virago, 1988), 306.

69 Julia Kristeva, Melanie Klein, trans. Ross Guberman (New York: Columbia University Press, 2001), 304.

70 Klein, Love, Guilt and Reparation, 190.
} 
stream of milk runs down the throat and fills the stomach'. ${ }^{71}$ This combination of needs and sensitivity lies at the roots of affects, and emotions.

The other side of infantile dependency is aggression, directed towards the body of the life-giving mother. When the breast is not there, Klein notes: 'the feelings of having lost the breast lead to the fear of having lost the loved mother entirely.72 Psychic life becomes ridden with a fear, sadness and aggression that may turn to depression. Depression, however, is not devastation - it, also, belongs to the origin of psychic life. The child is frustrated and sad at the loss of the breast. But these affects come with fantasies that are necessary aggression is an aspect of psychic life which is 'of highest value' to the child's mental development. ${ }^{73}$ The child eventually learns to integrate feelings of love and hatred, and synthesize the good and the bad as aspects of the mother. This entails a process of mourning. ${ }^{74}$

What differentiates Descartes from both Freud and Klein is the way in which affects are imbricated in a physical flow of juices. Love, in the life of the Cartesian as well as the Freudian subject, is aroused not just by physical encounters, but also by the 'object of love' presenting itself to the mind, that is, as representation. ${ }^{75}$ These, however, have direct physical effects. A loved object may produce, but also stimulate, a flow of 'alimentary juice', which is experienced as enjoyment. In this way, love is a self-enhancing circuit where enjoyment will lead the mind to dwell on that object and the body to crave more 'juice. ${ }^{76}$ In this way, emotions and affects belong to a circular flow. The representation of objects or partial objects might suffice to stimulate this flow of enjoyment: 'a single thought of joy or love or the like is sufficient to send the animal spirits through the nerves into all the muscles needed to cause the different movements of the blood which, as I said, accompany the passions.77 Animal spirits are, in this context, complementary to the blood and the nerves, an in-between organ that comes as 'very fine wind or air.' ${ }^{78}$ Appearing in the shape of different qualities, the spirits move the body, connecting muscles with the brain. In Passions as well as in The World and Treatise on Man, Descartes sees 'animal spirits' as a drive or flow internal to the body that connects moods

\footnotetext{
71 Klein, Love, Guilt and Reparation, 326.

72 Klein, 'Weaning,' in Love, Guilt and Reparation, 295.

73 Klein, 'Weaning,' in Love, Guilt and Reparation, 294.

74 Klein, Envy and Gratitude: A Study of Unconscious Sources (London: Tavistock, 1957), 32.

75 AT XI, 409; Descartes, Passions of the Soul, 74.

76 AT XI, 404; Descartes, Passions of the Soul, 74.

77 AT IV, 408, Descartes to Elisabeth, May 1646; PW III, 286.

78 AT XI, 332; Descartes, Passions of the Soul, 22.
} 
and ideas with somatic experiences. ${ }^{79}$ 'Animal spirits' offer a link between the somatic and the psychic.

The infant is dominated by an affective rhythmic flow, which intertwines the somatic and the psychic. Not only does this suggest mind and body to be interrelated. There is no longer a meaningful distinction to be made between inside and outside. Psychic representations - or fantasies - have been placed in the body, and the maternal body incorporated in experiences wavering between pleasure and displeasure, crossing the borders between inside/outside. We are brought to a body of instincts and fantasies where primary objects are incorporated. Love inscribes an original dynamic of wellbeing which joins bodily conditions and 'the corresponding thoughts'. ${ }^{80}$ Hate, in turn, is the instinct of discarding an object that may or not be real or appear as thought. It is the immediate denegation of an object at a corporeal level. ${ }^{81}$ The psychic associations from infantile life will produce similar flows also in the body of the adult, but they will retract from conscious knowledge of their original causes.

\section{Instincts, Sexuality and Repression}

Infantile life, from Formation of the Fetus to Passions of the Soul, remains unobtainable to adult consciousness. ${ }^{82}$ This is due to the immaturity of a child's brain. It does not form the 'traces' that connect with memories. ${ }^{83}$ Descartes, like Freud, posits an instinctual body lost to conscious memory - the origins of the passions being traced to the unborn child. ${ }^{84}$ The infant is bestowed with the capacity to love, is 'ticklish', has a readiness for pleasures and satisfactions, hate and anger - corporeal affects that 'do not remain in the memory'. ${ }^{55}$ For the adult, perceptions create psychophysiological imprints on mind and body. These imprints are identified as 'tubes' or 'traces' or 'folds' that are stored in the body, forming a link to representations. There has been controversy

79 John Sutton identifies the spirits as the radically new element in the Cartesian psychophysiology, which was otherwise based upon Renaissance theories of bodies that were fluid and permeable at large. See John Sutton, 'The Body and the Brain,' in Descartes' Natural Philosophy, ed. Gaukroger, Schuster, and Sutton, 697-722 (700-05).

8 o AT IV, 604, Descartes to Chanut, 1 February 1647; PW III, 307.

$81 \quad$ AT XI, 387; Descartes, Passions of the Soul, 62.

82 This has been noted by Cottingham, who sees in Descartes a new route for the 'therapy' of passions; the 'physician' of passions does not avoid them, but sorts them by reason. Cottingham, Philosophy and the Good Life, 92.

83 AT VII, 357; PW II, 247.

84 AT IV, 6o6, Descartes to Chanut, 1 February 1647; PW III, 6 o8.

85 AT IX, 190; PW II, 171-72. 
surrounding this description: does it mean that memory traces are 'finite' when storage runs out of space? But Descartes seems rather to have implied that memory is a continuous process that becomes modified over time, linking intellectual and corporeal processes. ${ }^{86}$ Through this scheme, Descartes formulates a theory of repression.

The thoughts 'that have accompanied some movements of our body since our life began still accompany them today'. ${ }^{87}$ These reactions, or 'thoughts', stay with us and are actualised by external causes that may 'arouse the same thoughts', whereas thoughts arouse the same movements. Emotional memories are incorporated since childhood, and we cannot tell where emotions come from: they hit us without us knowing why. The 'thought' of the infant pertains to the body impinging on it. In the mind of the adult, this happens through corporeal representations: the mind is set in motion 'when the mind joined to a body thinks of a corporeal thing.' ${ }^{88}$ Such corporeal representations can be affects, emotions, objects or names with corporeal implications

Infantile affective memories can be stored, unobtainable to consciousness. It is as if the traces of infantile affects hide in the body, its connections, tubes and flows. In Formation of the Fetus, infants are shaped by an original fetal enclosure. This symbiotic relation to the maternal body gives a floating status to the beginning of life, childhood being a continuation of the fetal state dominated by the search for enjoyment. Freud thought that breastfeeding awakens auto-erogenous zones: 'No one who has seen a baby sinking back satiated from the breast and falling asleep with flushed cheeks and a blissful smile can escape the reflection that this picture persists as a prototype of the expression of sexual satisfaction in later life'.89 Freud, like Descartes, speaks about the child as essentially auto-erotic. ${ }^{90}$ Its polymorphous perversity makes the whole body of the child into a pleasure-seeking erogenous zone, what Lacan has called a montage of partial drives. ${ }^{91}$

To Descartes, also, children seek a pleasure that hinges on sexuality: when the lips of a sleeping child are tickled by a feather, the ticklish enjoyment

86 See John Sutton, who argues that Descartes was trying to form his theory of memory traces so that new impressions could always be made, animal spirits being used to keep the process of a continuous flow. John Sutton, Philosophy and Memory Traces: Descartes to Connectionism (Cambridge: Cambridge University Press 1998), 64-65.

87 AT IV, 408, Descartes to Elisabeth, May 1646; PW III, 286.

88 AT III, 424-25; PW III, 19 o.

89 Freud, SE VII, 182.

9o Freud, SE VII, 197 .

91 Jacques Lacan, The Four Fundamental Conceots of Psychoanalysis, trans. Alan Sheridan (New York: Norton \& Norton, 1998), 177-78, 183. 
is direct - a scene bringing Freud's recounting of a dream from Leonardo da Vinci's childhood to mind. In the dream, the boy opens his mouth to a bird's tail. To Freud, this is a fantasy of suckling, embracing and kissing the mother. ${ }^{92}$ To Descartes, enjoyment entangled with love excites the instinct to 'open our arms as if to embrace something', a reference to sexual lust. ${ }^{93}$ There is a difference between sexual and 'metaphysical' desire and love. But the love of the child is never without lust. Just like in psychoanalytical descriptions, the 'confused sensations of our childhood', the dignified nature of love becomes intermingled with joy, sadness, desire fear and hate. ${ }^{94}$

In 'Instincts and their Vicissitudes', Freud affirms the all-encompassing domination of the pleasure principle of the psyche in what will become a first theory of the drive. An 'instinct' is 'a concept on the frontier between the mental and the somatic, as the psychic representative of the stimuli originating from within the organism and reaching the mind, as a measure of the demand made upon the mind for work in consequence of its connection with the body' ${ }^{95}$ Descartes, like Freud, affirms the instinctual nature of love through the child. He does so, perhaps unsurprisingly, with a model that even more distinctly holds on to the somatic nature of instincts. If the problem for Descartes is the nature of 'confused thought' and its origination in the life of the infants, with the 'thinking fetus' swamped in emotions and affects at the roots of the Cartesian genealogy, then he needs to find not just mental images for the zone in between subject and object, body and mind, but also more distinctly somatic zones.

The womb, and the navel, are such zones. In Formation of the Fetus, the womb connecting mother and child is an organ not only of blood, but also of spirits. The last organ of the fetus to be formed, by semen, is the navel. Blood flows through it and forms the heart, which is the original site of the passions. ${ }^{96}$ The navel is a line of connection for the 'spirits', which forms emotions in the fetal joining of body and blood. ${ }^{97}$ The stronger the emotion, the more movement: 'love depends upon an abundance of spirits. ${ }^{98}$ As we come out into the world, some 'juice' enters into the veins of the heart and gives it the 'flow of life. ${ }^{99}$ The soul, he argues further, loves this. It joins itself to the body de volonté, 'in

\footnotetext{
92 AT XI, 6; PW I, 82. Cf. Freud, SE XI, 107.

93 AT IV, 603, Descartes to Chanut, 1 February 1647; PW III, 307.

94 AT IV, 6o6; PW III, 308. Cf. AT XI, 388; Descartes, Passions of the Soul, 62-63.

95 Freud, 'Instincts and their Vicissitudes,' in SE XIV, 122.

96 AT XI, 274; Descartes, The World, 198.

97 AT XI, 266; Descartes, The World, 194.

98 AT X, 167; Descartes, The World, 141.

99 AT XI, 407; Descartes, Passions of the Soul, 77.
} 
volition' This is not conscious will. It can be read against the background of early modern theology. 'It is the nature of love to make one consider oneself and the loved one as a single whole of which one is a part; and to transfer the care one previously took of oneself to the preservation of this whole.' ${ }^{100}$ This is by no means a mere spiritual experience. The soul learns to join this nourishment to itself from the body 'in volition, that is, to love it.'.101 The spirits flow from the brain to the muscles, shaking the body so that the heart is fuelled, 'to make them send it more.'102 We love to feel the inside flow.

In this way, the concept de volonté, in volition, designates a move not only between body and mind, but also between subject and object. The subject experiences an 'excitation', which impels it to join itself 'in volition' to objects of pleasure. ${ }^{103}$ Descartes does not use the phrase de volonté to talk about desire, he explains; it refers to the instinct to join with the objects we love. ${ }^{104}$ At this point, 'in volition' refers to sexual drive. Finding its origin in an archaic object, it is also transposed into adult sexuality, the warmth of blood raising desires in the sexual organs, the 'organs designed for generation.' ${ }^{105}$ Again, metaphysical concepts overshoot their use and blend into the scheme of a body which is propelled by drives that extend their domination from infancy to adulthood, from the polymorphously perverse body to genital sexuality.

In Freud's Three Essays on Sexuality, the breastfeeding child, the oral sensations of suckling, form the 'prototype of the expression of sexual satisfaction in later life.' ${ }^{106}$ Freud identifies the separation between the enjoyment of lactation and sexual stimulation as a split preceding infantile amnesia and repression. ${ }^{107}$ Although childhood is a period in life of extraordinary sensual and emotive force, people tend to have no memories of it. This childhood amnesia, Freud explains, is due to the fact that the strong affects become associated with the sexual impulses of childhood, which have been repressed. ${ }^{108}$

To Descartes, also, we are, as children, marked by instincts that we tend to forget as adults. Our bodies are enveloped by pain and pleasure. As adults, we have difficulties remembering this exposure: 'no traces of these thoughts have been imprinted on the brain', as we read in Descartes's conversation with

\footnotetext{
100 AT IV, 6o1-17, Descartes to Chanut, 1 February 1647; PW III, 305-14.

101 AT XI, 4O7; Descartes, Passions of the Soul, 77.

102 AT XI, 408, Descartes, Passions of the Soul, 77.

103 AT XI, 387, Descartes, Passions of the Soul, 61.

104 AT XI, 387, Descartes, Passions of the Soul, 61.

105 AT XI, 128; my translation.

106 Freud, SE VII, 182.

107 Freud, SE VII, 182.

108 Freud, SE VII, 175 .
} 
Burman. ${ }^{109}$ Still, mind and body are joined through certain original experiences. These may be produced by sense organs and outside objects, but also by the so-called 'animal spirits' and by our own thoughts: 'the motion of these brain particles leaves behind the traces on which memory depends.'110

Confused thoughts are a bundle of ideas and corporeal impulses that cannot be dissociated. This pertains also to the fact that we cannot use our will to love or control our desire. We feel desire towards objects against our wishes, and we are unable to love objects we would like to love. Affective memories may hit us beyond our control. In Passions, Descartes describes how the brain, as we are affected by something, acts on traces that have already been set before: 'pores of the brain through which the spirits previously made their way', thereby facilitating new impressions to awake memories. This is, for some memories, directed by the will. ${ }^{111}$ But this is not the case with affects. They can be awakened only 'indirectly by the representation of things which are usually joined with the passions.'112 The brain creates 'folds' as it is struck by the nerves stimulated by the senses. These folds have a tendency to be stimulated by the same objects. ${ }^{113}$ Emotions are not produced in our minds but received 'from things represented by them.'114 Animal spirits create movements between memories, affects and representations, and the body. ${ }^{115}$ Traces of a childhood prehistory may then trigger the whole system, and perturbate the mind as well as the physiological body. ${ }^{116}$

Dreams, fantasies, memories and emotions are all part of a circuit. The cause of emotions lies not in the external world, but within us, in the traces that produce a flow between mind and body. ${ }^{117}$ The associative stream of dreams, fantasies and memories are linked to such traces. These in turn are associated with emotions and affects, just like the dynamic of mnemonic traces that Freud inscribes in the final chapter of the Interpretation of Dreams. The similarity also extends to Freud's explanation of the paths of association

\footnotetext{
109 Descartes, Conversation with Burman, 8.

110 AT III, 424; PW III, 19 o.

111 AT XI, 350; Descartes, Passions of the Soul, 41.

112 AT XI, 362-63; Descartes, Passions of the Soul, 43.

113 AT V, 15o, Descartes to Chanut, 6 June 1647; PW III, 336.

114 AT XI, 342, 362; Descartes, Passions of the Soul, 28, 43.

115 As John Sutton has noted, this dynamic view of the animal spirits made them popular in Descartes's own times and helped introduce a dynamic physiological psychology through which an absent past could be reconstructed: 'temporal continuity could only be provided by recurring patterns of fluid motions across new contexts.' Sutton, Philosophy and Memory Traces, 49 .

116 AT IV, 408, Descartes to Elisabeth; PW III, 286.

117 AT XI, 362; Descartes, Passions of the Soul, 43 .
} 
through traces marked by affects. The mnemonic traces can be remnants of images or language, but also of emotions. ${ }^{118}$ In the psychic apparatus, they are associated, displaced and condensed. Descartes argues in a similar manner: once a corporeal affect is established in connection with a representation, it will always be connected, but 'the same actions are not always joined to the same thoughts' ${ }^{119}$ In other words, the relation between traces of perceptions and emotions are continuously deferred, so that representations and emotions will shift. Certain original affects remain joined to the body and become actualised in adult life. The child does not remember what it has experienced, but the 'memory' of these affects may appear by way of the animal spirits, offering a link between traces. ${ }^{120}$

Cartesian traces of the mind are to be understood in the literal sense, as neurological markers. But what separates Descartes's speculation from contemporary neuroscience is the flow between bodies: not only will the child react on traces from its own experiences - cat-phobia is the result of infantile experiences of fear - but also the mother's experience. A mother's emotions and affective states will pass on directly to her child, although they will remain repressed. But strong affects suffered by a mother will be transposed to the child in the womb: 'what is adverse to the one is harmful to the other'. The experience will remain 'imprinted in his brain to the end of his life.'121

Such was the case of Descartes's first love, a girl who had slightly crossed eyes. Similar squints continued to raise desire later in life: 'yet I had no idea myself that this was why it was'. The affect remained with the object, similar to something 'in an earlier object of love, though we may not be able to identify it.' ${ }^{\prime 22}$ Affects appeared associative, as memory traces: for a long time, Descartes would be affected by desire at the sight of crossed eyes.

In Passions of the Soul, he returns to this feeling of fixation on a unique feature in a person, principal points of fascination also in literary romances. ${ }^{123}$

118 Freud, Interpretation of Dreams, SE IV-V, 537-41. Freud describes the dream thought apparatus as a kind of accumulated resource of traces of perceptions rendered unconscious, that through certain association and stimulations might become preconscious and result in a motor discharge.

119 AT XI, 429; Descartes, Passions of the Soul, 91.

120 See Véronique Foti, 'Presence and Memory: Derrida, Freud, Plato, Descartes,' Graduate Faculty Philosophy Journal 11, no. 1 (1986): 67-81.

121 AT XI, 429; Descartes, Passions of the Soul, 91.

122 AT V, 57, Descartes to Chanut, 6 June 1647; PW III, 322. This letter is mentioned by Henri F. Ellenberger as referring to an 'unconscious or half-conscious memory.' Ellenberger, The Discovery of the Unconscious: The History and Evolution of Dynamic Psychiatry (New York: Basic Books, 1970), 523 .

123 AT XI, 396; Descartes, Passions of the Soul, 6. 
In a letter authored a few months after the 'letter of love', Descartes explains love in terms that are more neurological than theological. Attraction can be explained by the disposition of the parts of our brain:

The objects which touch our senses move through the intermediary of the nerves to some part of our brain ... When we are drawn to love someone without knowing the cause, we can believe that this comes from something in the object which is similar to what was in a previous object we once loved. ${ }^{124}$

Our desire is re-found, directed as it is toward a trace or shadow of an object. Melanie Klein put it in a similar way: infantile dependency will later transfer love to other objects - 'replacing the first loved person by other objects and things. ${ }^{125}$ Freud, in a famous passage from the second of the Three Essays on Sexuality, spoke of sexualisation of the object forming après-coup: 'At a time when the first beginnings of sexual satisfaction are still linked with the taking of nourishment ... the sexual instinct has a sexual object outside the infant's own body in the shape of his mother's breast'. This is then transferred onto the mother. But 'not until the period of latency has been passed is the original relation restored. There are thus good reasons why a child suckling at his mother's breast has become the prototype of every relation of love. The finding of an object is thus in fact a re-finding of it'. ${ }^{126}$

Descartes has no explicit theory of the sexual drive. There is no latency period, or any distinction between the polymorphously perverse body of the child and the sexual love of the adult. And yet, with the confused thoughts of the infant, Descartes stresses the corporeal imprints on the mind. The nature of love escapes from conscious understanding, since it remains caught in the affects of our childhood. ${ }^{127}$ The unavailability of traces and memories to conscious will, will cement 'the impossibility of self-knowledge', which in the words of John Sutton characterised both the Cartesian and the Freudian

\footnotetext{
124 AT V, 57; PW III, 322-23. As Cottingham has noted, a 'therapy' of the passions would then involve going back to the history of our early lives. Cottingham, Philosophy and the Good Life, 93. In a comparison to the writings on trauma, hysteria and repression in early Freud, Matthew Eshleman discusses the Cartesian conception as neurological. Eshleman, 'The Cartesian Unconsciousness,' History of Philosophy Quarterly 24, no. 3 (2007): 297-315 (299).

125 Klein, Love, Guilt and Reparation, 326.

126 Freud, SE VII, 222.

127 AT IV, 6o6, Descartes to Chanut, 1 February 1647; PW III, 308.
} 
project. ${ }^{128}$ The most archaic emotions and affects will always mark the life of the subject, but the adult will carry them unknowingly.

In this way, not only does the theory of the thinking fetus challenge the dogma of the mind-body division that has been associated with Descartes's name. It presents a trajectory of research on the infant that supplants his better-known metaphysics. This is a trajectory that deserves our attention, not only for the way in which it paves the way for psychoanalysis, and later on neuropsychology, studying the way in which the mind keeps and transports memories, emotions and affects. In this trajectory, we also find the presence of a maternal body that may be of little consequence to the history of metaphysics but of great consequence to the Cartesian understanding of psychic life.

128 Sutton, 'The Body and the Brain,' 699. 